\title{
Relationship between the Normalized Difference Vegetation Index (NDVI) and Some Soil Characteristics in the North of Iraq
}

\author{
*Alaa Salih Ati, ${ }^{*}$ Abdulghafour Ibrahim, ${ }^{* * *}$ Amel Radhi Jubair \\ ${ }^{*}$ Prof. Soil Sci. Dept. College of Agric/ Univ. of Baghdad-Iraq \\ ** Lecturer Soil Sci. Dept. College of Agric/ Univ. of Baghdad-Iraq \\ *** Lecturer Soil Sci. Dept. College of Agric/ Green Univ. of Al Qasim-Iraq
}

\begin{abstract}
To perform a good classification for vegetation by using Remote Sensing data. In this research the study area located in the Erbil and Sulaimanya governorates are located on longitude $36^{\circ} 11^{\prime} 24^{\prime \prime}$ North $44^{\circ} 06^{\prime}$

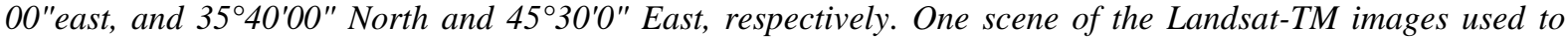
investigate changes of the vegetation distribution by Normalized differential vegetation index (NDVI), the results referred to more green areas in Erbil than Sulaimanya, that's mean, the no vegetation area increased by 247.14 ha because some barren soil and water bodies increased in Sulaimanya. The dense vegetation area increased too in Sulaimanya and poor vegetation decreased because the agriculture exploitation of the land but the other vegetation classes such as moderate, very dense vegetation decrease with small amount. The highest values of Kast in studied sites were 60.89, 60.34, 77.73, 55.12 and $88.67 \mathrm{~cm} . \mathrm{hr}^{-1}$ recorded in surface horizons of P1, P2, P6 (Sulaimanya sites) and P1, P2 (Erbil sites) respectively. The reason of upturn value in hydraulic conductivity was the effect of organic matter content which led to decrease the bulk density and higher porosity, MWD. Pedon 3 in Erbil site situated within the classification dense vegetation, while the pedon 3 Sulaimanya site and pedon 4 Erbil site situated within the classification moderate vegetation, Pedon 5 Sulaimanya site placed within classification poor vegetation, was due to high free iron oxides content in this site.
\end{abstract}

Keyword: Remote sensing, NDVI, Landsat, Kast.

\section{Introduction}

NDVI is a commonly used and easily calculated satellite image-based proxy for vegetation productivity Kunkel, 2011 and Scanlon, 2002. Soil and vegetation resources are closely correlated, soils influence plants, and plants affect the characteristics of soils inversely Allen EB, 1991. Extreme events, such as droughts under climate change could increase soil desertification especially in arid and semi-arid environment. Desertification refers to land degradation; it is basically defined as a reduction in the biological productivity of the land (Prince, 2002 and Wessels et al., 2004). Vegetation indices are defined as dimensionless, radiometric measures that function as indicators of relative abundance and activity of green vegetation, often including leaf-area index, percentage green cover, chlorophyll content, green biomass, and absorbed photo-synthetically active radiation (Jensen, 2000). Indices such as Normalized Difference Vegetation Index (NDVI) reflect the overall effect of rainfall and soil moisture on crops and play an important role in drought monitoring and early warning.

The NDVI has become the most important tool for monitoring and detecting drought impacts on agriculture (Dabrowska-Zielinska et al., 2002 and Singh et al., 2003). Since climate is a key factor affecting vegetation conditions, the NDVI has been widely used at regional and global scales to identify weather impacts on crop growth conditions and yields (Li and Lewis, 2004; Vicente-Serrano et al., 2006 and Jain et al., 2009). Fadhil (2011) pointed to the useful of using the NDVI to detect drought impacts in Kurdistan region of Iraq. The study showed a significant decrease in vegetation cover $(56.7 \%)$ and a decline in soil/vegetation wetness (29.9\%). Agriculture drought is one of the most important and lowest studied issues in Iraq. Water deficiency is studied from hydrological and political perspectives (Rasheed, 2010). There are few studies on the effect of drought stress on agricultural sector, thus this study aims to:

1. Show the relationship between soil physical and chemical properties with vegetation distribution.

2. Detect drought emergence and severity for some governorates of Iraq using the NDVI index.

Materials and Methods

Description of the Study Area/ Location and area

The study area (fig.1) located in the Erbil and Sulaimanya governorates are located on longitude $36^{\circ} 11^{\prime} 24^{\prime \prime}$ North $44^{\circ} 06^{\prime} 00^{\prime \prime}$ east, and $35^{\circ} 40^{\prime} 00^{\prime \prime}$ North and $45^{\circ} 30^{\prime} 0$ " East, respectively. 


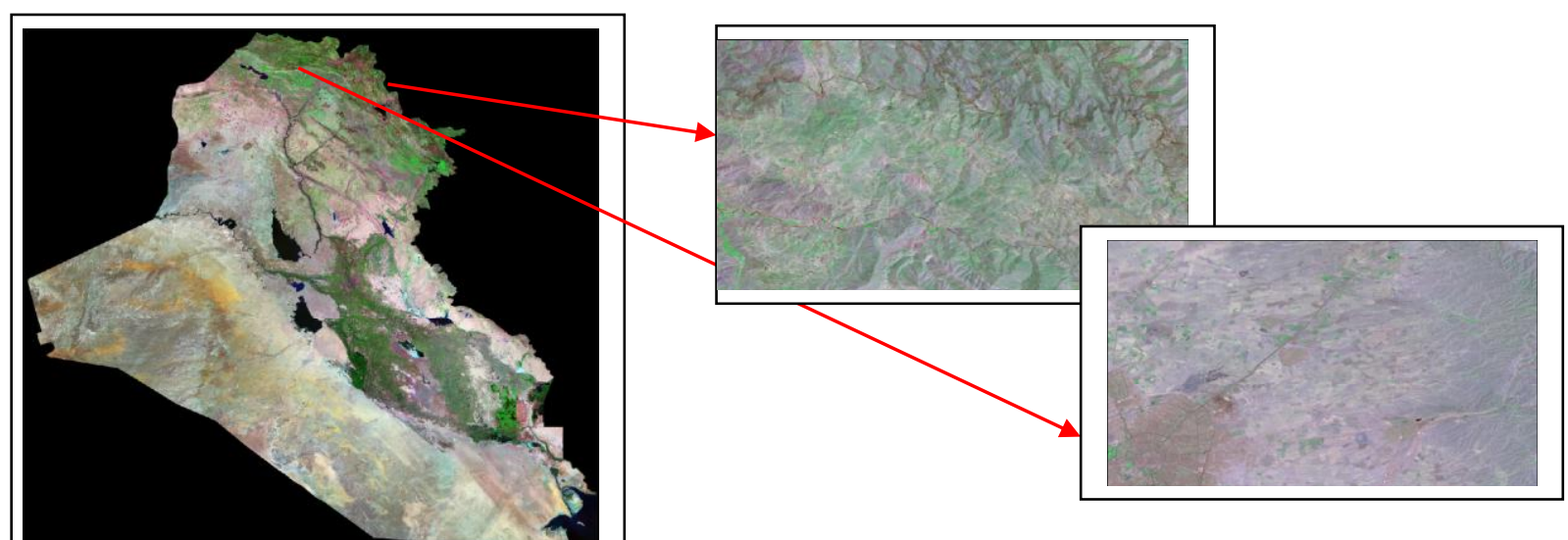

Figure (1) shows the study area sites

\section{Remote sensed dataset}

To investigate changes of the vegetation distribution in north of Iraq one scene of the Landsat-TM images of July 23, 2006. The Landsat image consists of seven bands. The characteristics of this Image were show in Table 1.

Table 1: The characteristics Landsat TM sensor image

\begin{tabular}{||c|c|}
\hline \multicolumn{1}{|c|}{ Landsat-5TM } & Spatial Resolution \\
\hline \hline 1. 0.45-0.52 (Blue) & $30 \mathrm{~m} * 30 \mathrm{~m}$ \\
2. 0.52.0.60 (Green) & $30 \mathrm{~m} * 30 \mathrm{~m}$ \\
3. 0.63-0.69 (Red) & $30 \mathrm{~m} * 30 \mathrm{~m}$ \\
4. 0.76-0.90 (NIR) & $30 \mathrm{~m} * 30 \mathrm{~m}$ \\
5.1.55-1.75 (Mid-infrared) & $30 \mathrm{~m} * 30 \mathrm{~m}$ \\
6.10-4-12.5 (Thermal) & $120 \mathrm{~m} * 120 \mathrm{~m}$ \\
7. 2.08- 2.35 (mid-NIR) http://www.usgs.gov.2012 & $30 \mathrm{~m} * 30 \mathrm{~m}$ \\
\hline
\end{tabular}

All the remote sensing process and geographic information systems carried out at the College of Agriculture/University of Baghdad/Soil and water Resources Department.

\section{Classification}

Unsupervised classification was applied as first step to obtain an overview of the spectral differences of the study area. The unsupervised classification result was then used for defining the training areas (using, ERDAS Imagine ver. 10). The training areas were detected with the help of GPS in the field work Erdas Imagine was used for expanding the training area from single coordinate point recorded by the GPS device.

\section{The soil physical and chemical analyses}

Disturbed soil samples were air- dried and passed through a sieve of $2000 \mu \mathrm{m}$ to determine chemical, physical and 4000- $9000 \mu \mathrm{m}$ sieve to determine aggregate stability parameters. Some physical characteristics measured included: Particle size distribution, bulk density $(\rho b)$, total porosity $(f)$, mean weight diameter (MWD) and hydraulic conductivity (Ksat), as well as chemical characteristics measured included: Calcium carbonate $\left(\mathrm{CaCO}_{3}\right)$, cation exchange capacity (CEC), Organic matter (OM), EC and pH of studied pedon according to Black et al. (1965) (part 1 and 2).

\section{Vegetation Indices}

The remotely sensed dataset based vegetation indices were utilized in this study to map the vegetation status during the study period. The vegetation indices were Normalized differential vegetation index (NDVI):

$$
\text { NDVI= }(\text { TM4-TM3) / }(\text { TM4+TM3) }
$$

\section{Produce final maps in GIS environment}

The main processes in gathering and analyzing the remotely sensed data set remotely sensed dataset of the study area were analyzed qualitatively by visual interpretation and qualitatively using Spectral Mixture Analysis and other indices. The combination of both statistical analyses and spectral change detection techniques were applied to investigate and analyses the results and map production by using geostatistical. 


\section{Result and Discussion}

Normalized Difference Vegetation Index (NDVI)

Red light is strongly absorbed by photosynthetic pigments (such as Chlorophyll) found in green leaves, while near infrared light either passes through or is reflected by leave tissues, regardless of their color. It means that the areas of bare soil having little or no green plant material are similar in both red and near infrared wavelengths, The areas with much green vegetations show more brightness in the near-infrared and are very dark in the red part of the spectrum (Yousef et al., 2006). The total area in study area (Erbil) of the vegetation cover which extracted by using the NDVI image (Fig.3) were 2,7328.95 ha. The no vegetation, poor vegetation, moderate vegetation, dense vegetation, very dense vegetation areas were covered 1688.58 ha $(6.18 \%), 6495.03$ (23.77\%), $7632.66(27.93 \%), 7251.48$ (26.53\%), 4261.23 (15.60\%), respectively (Fig.4 and Table 2).

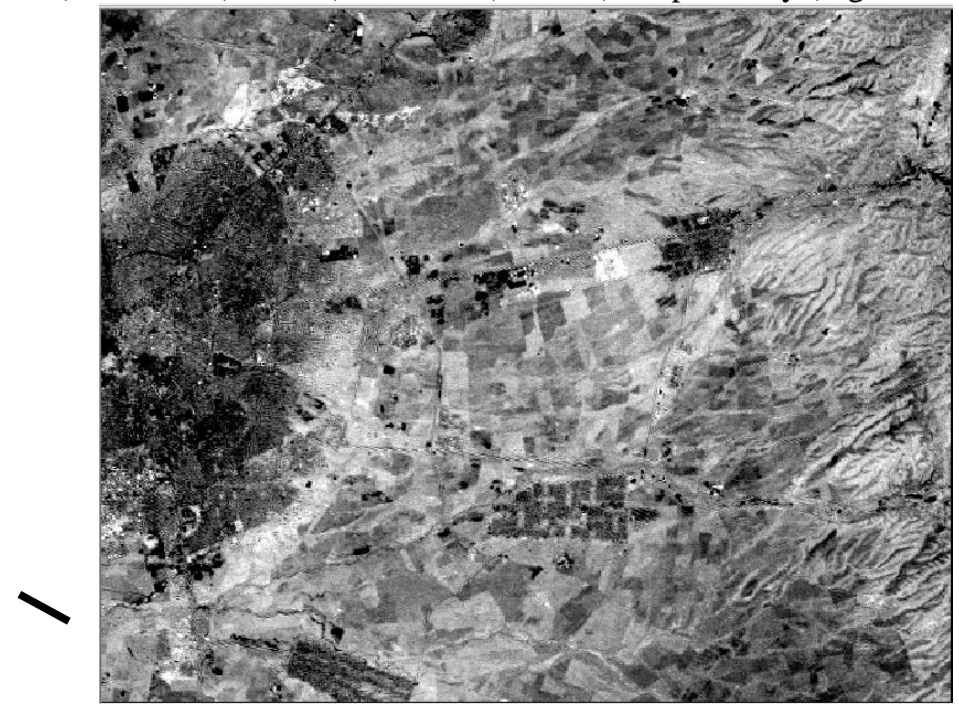

Scale 1:120,000 Figure (3) The NDVI images of study area

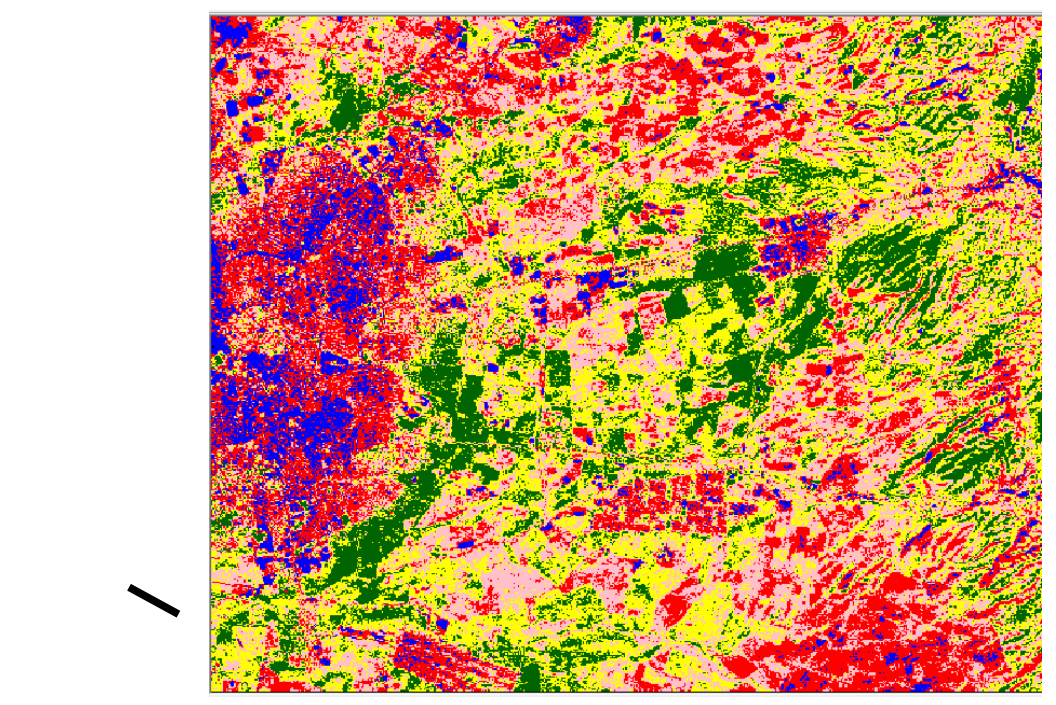

Scale 1:120,000 Figure (4) The Vegetation classes of study area (Erbil)

\begin{tabular}{|l|l|r|}
\hline & No vegetation & 1688.58 \\
\hline \hline & Poor vegetation & 6495.03 \\
\hline & Moderate vegetation & 7632.63 \\
\hline & Dense vegetation & 7251.48 \\
\hline & Very dense veqetation & 4261.23
\end{tabular}

The total area in the second study area (Sulaimanya) of the vegetation cover which extracted by using the NDVI image (Fig.5) were 2,7362.97 ha. The result referred to no vegetation, poor vegetation, moderate vegetation, 
dense vegetation, very dense vegetation areas were covered 1935.72 ha(7.07\%), 6105.87 (22.31\%), 7586.1(27.72\%), 7520.94(27.48\%), 4214.34(15.40\%), respectively (Fig.6 and Table 2).
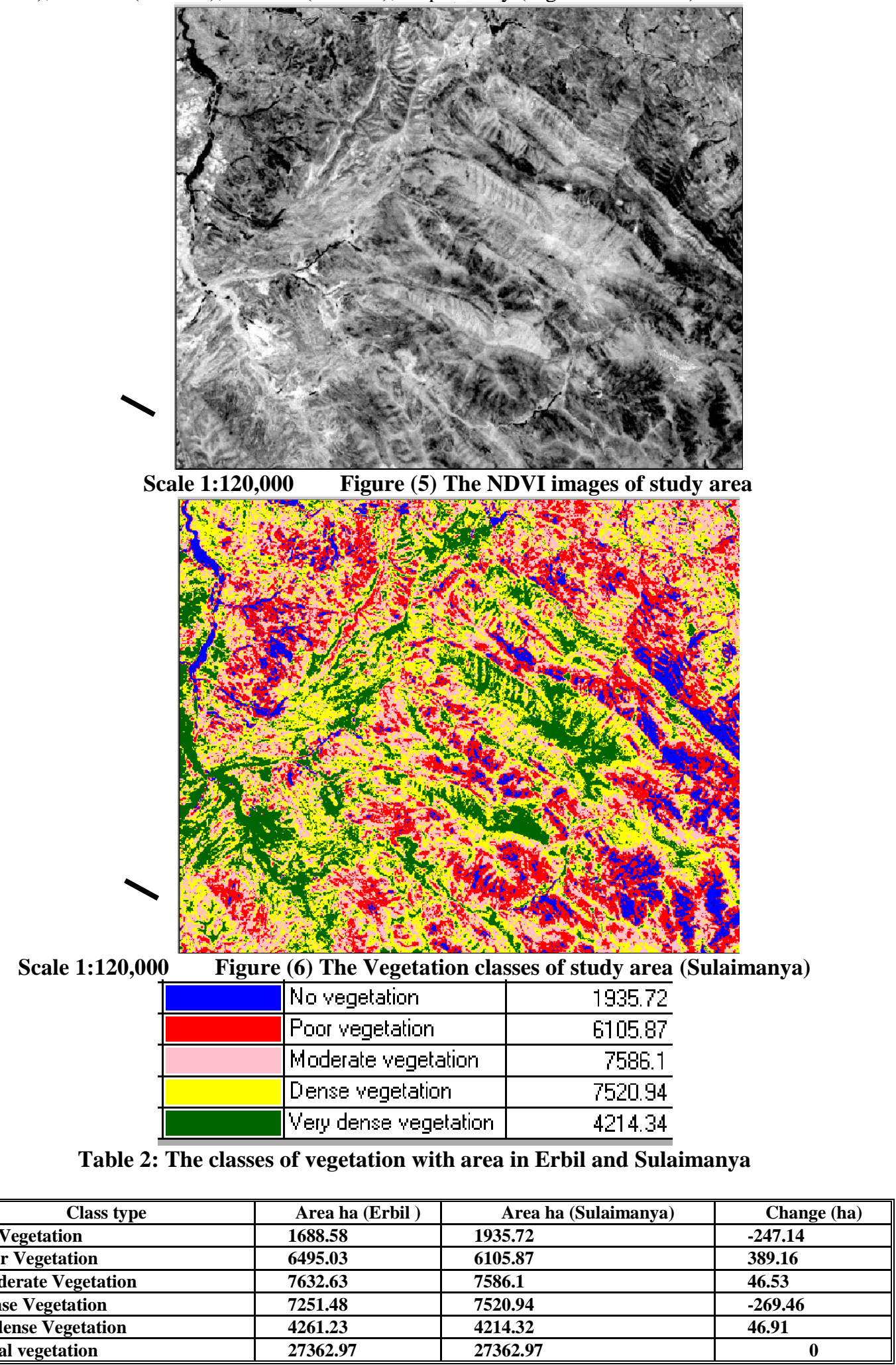

\begin{tabular}{||l|l|l|l||}
\hline \multicolumn{1}{|c|}{ Class type } & Area ha (Erbil ) & Area ha (Sulaimanya) & Change (ha) \\
\hline No Vegetation & 1688.58 & 1935.72 & -247.14 \\
\hline Poor Vegetation & 6495.03 & 6105.87 & 389.16 \\
\hline Moderate Vegetation & 7632.63 & 7586.1 & 46.53 \\
\hline Dense Vegetation & 7251.48 & 7520.94 & -269.46 \\
\hline V.dense Vegetation & 4261.23 & 4214.32 & 46.91 \\
\hline Total vegetation & 27362.97 & 27362.97 & 0 \\
\hline
\end{tabular}

The results referred to more green areas in Erbil than Sulaimanya, that's mean, the no vegetation area increased about 247.14 ha because some barren soil and water bodies increased in Sulaimanya. The dense vegetation area increased too in Sulaimanya and poor vegetation decreased because the agriculture exploitation of the land but the other vegetation classes such as moderate, very dense vegetation decrease with small amount. 
Some of physical properties involved in evaluation of the soil quality accredited by USDA-NRCS (2001) were estimated (Table 3). It focused on the some physical properties a direct impact on the soil quality and plant growth, including texture, bulk density and aggregate stability and saturated hydraulic conductivity. It is noted the pedons variation in physical characteristics relevant evidence the soil quality. Noting that texture prevailing surface layer ranged from clay to clay loam and this reflects the impact of the situation prevailing in the study area sedimentary.

The results indicate that the values of bulk density of the surface layer of the soil has ranged between $1.19 \mu \mathrm{g}$. $\mathrm{m}^{-3}$ to $1.55 \mu \mathrm{g} . \mathrm{m}^{-3}$ on the AP horizon for pedon 4 (Erbil) and pedon 2 (Sulaimanya) respectively, these results are consistent with the case of variation in the tissues of soil as well as the impact factor management and use soil for different purposes. Also, shown the pedons study a clear divergence in the values of the mean weight diameter since ranged between $4.45 \mathrm{~mm}$ to $1.63 \mathrm{~mm}$ on the AP horizon for pedon 2 and 3 (Erbil), due to the direct effect of each of the soil content of clay as well as organic matter and calcium carbonate, as shown clear contrast in content of these components has been reflected on the nature aggregate. As well as the results showed that the values of hydraulic conductivity ranged between $0.47 \mathrm{~cm} . \mathrm{h}^{-1}$ (pedon 5 Sulaimanya) to 88.07 $\mathrm{cm}$. $\mathrm{h}^{-1}$ (pedon 2 Erbil) influenced by the qualities of fixed soil which texture as well as the dynamic characteristics: organic matter and cation exchange capacity.

Table 3: Particle size distribution, Bulk Density $(\rho b)$, Total Porosity $(f)$, Mean Weight Diameter (MWD) and Hydraulic Conductivity (Ksat) of studied pedon

\begin{tabular}{|c|c|c|c|c|c|c|c|c|c|c|c|}
\hline \multirow[t]{2}{*}{ governorate } & \multirow[t]{2}{*}{ Pedon } & \multirow[t]{2}{*}{ Horizon } & Depth & Sand & Silt & Clay & Tex. & \multirow{2}{*}{$\begin{array}{c}\begin{array}{c}\text { Bulk } \\
\text { density }\end{array} \\
\mu \mathrm{g} \cdot \mathrm{m}^{-3}\end{array}$} & \multirow{2}{*}{$\begin{array}{c}\text { Porosity } \\
\% \\
\end{array}$} & \multirow{2}{*}{$\frac{\text { MWD }}{\mathrm{mm}}$} & \multirow{2}{*}{$\begin{array}{c}\mathrm{K}_{\mathrm{sat}} \\
\mathrm{cm} \cdot \mathrm{h}^{-1} \\
\end{array}$} \\
\hline & & & $\mathrm{cm}$ & \multicolumn{4}{|c|}{ g. $\mathrm{kg}^{-1}$} & & & & \\
\hline \multirow{16}{*}{ 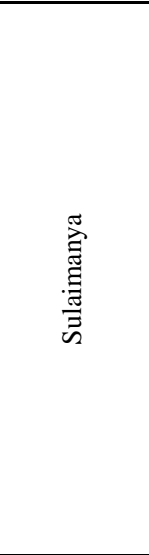 } & \multirow{4}{*}{$\mathrm{P}_{1}$} & $\mathrm{~A}$ & $0-25$ & 109 & 364 & 527 & $\mathrm{C}$ & 1.51 & 43 & 2.87 & 60.89 \\
\hline & & $\mathrm{Bt}_{1}$ & $25-35$ & 103.3 & 263.2 & 633.5 & $\mathrm{C}$ & 1.63 & 38 & 3.21 & 63.12 \\
\hline & & $\mathrm{Bt}_{2}$ & $35-70$ & 130.6 & 321.9 & 547.5 & $\mathrm{C}$ & 1.77 & 33 & 2.22 & 52.11 \\
\hline & & $\mathrm{Bt}_{3}$ & $70-150$ & 68.7 & 224.7 & 706.6 & $\mathrm{C}$ & 1.83 & 32 & 2.12 & 51.33 \\
\hline & \multirow{4}{*}{$\mathrm{P}_{2}$} & Ap & $0-25$ & 479.7 & 321.15 & 199.1 & $\mathrm{~L}$ & 1.55 & 36 & 2.56 & 60.34 \\
\hline & & $\mathrm{AB}$ & $25-80$ & 333.1 & 474.37 & 192.5 & $\mathrm{~L}$ & 1.43 & 41 & 2.1 & 56.23 \\
\hline & & $\mathrm{Bt}$ & $80-120$ & 503.1 & 256.2 & 240.7 & SCL & 1.39 & 40 & 2 & 58.21 \\
\hline & & Btk & $120-180$ & 393.9 & 307.2 & 298.9 & $\mathrm{CL}$ & 1.45 & 40 & 1.82 & 42.56 \\
\hline & \multirow{2}{*}{$\mathrm{P}_{3}$} & Ap & $0-20$ & 51.3 & 386.5 & 562.3 & $\mathrm{C}$ & 1.44 & 44.54 & 2.24 & 9.89 \\
\hline & & $\overline{\mathrm{AB}}$ & $20-70$ & 37 & 344 & 620 & $\mathrm{C}$ & 1.35 & 47.95 & 0.5 & 2.07 \\
\hline & \multirow{2}{*}{$\mathrm{P}_{4}$} & Ap & $0-25$ & 50 & 398 & 552 & $\mathrm{C}$ & 1.37 & 47.39 & 1.62 & 15.88 \\
\hline & & $\mathrm{Bt}$ & $25-80$ & 46 & 382 & 572 & $\mathrm{C}$ & 1.39 & 46.68 & 1.84 & 5.65 \\
\hline & \multirow{2}{*}{$\mathrm{P}_{5}$} & Ap & $0-20$ & 540 & 254 & 212 & SCL & 1.49 & 43.63 & 3.52 & 0.47 \\
\hline & & $\mathrm{Bt}$ & $20-75$ & 152 & 595 & 253 & SiL & 1.41 & 46.7 & 1.4 & 0.47 \\
\hline & \multirow{2}{*}{$\mathrm{P}_{6}$} & Ap & $0-25$ & 35 & 357 & 608 & $\mathrm{C}$ & 1.19 & 54.07 & 2.45 & 77.73 \\
\hline & & $\mathrm{Bt}$ & $25-75$ & 23 & 358 & 619 & $\mathrm{C}$ & 1.55 & 40.44 & 1.18 & 3.77 \\
\hline \multirow{10}{*}{ 룰 } & \multirow{3}{*}{$\mathrm{P}_{1}$} & Ap & $0-25$ & 286.5 & 396.2 & 317.3 & $\mathrm{CL}$ & 1.44 & 40 & 3.21 & 55.12 \\
\hline & & Bt1 & $25-75$ & 333.9 & 265.5 & 400.6 & $\mathrm{CL}$ & 1.51 & 38 & 2.76 & 43.33 \\
\hline & & Bt2 & $75-100$ & 318.8 & 295.75 & 385.4 & $\mathrm{CL}$ & 1.61 & 36 & 2.11 & 41.11 \\
\hline & \multirow{3}{*}{$\mathrm{P}_{2}$} & Ap & $0-25$ & 310.7 & 272.1 & 417.2 & $\mathrm{C}$ & 1.31 & 42 & 4.45 & 88.67 \\
\hline & & $\mathrm{Bk}$ & $25-75$ & 436.3 & 359.55 & 204.1 & $\mathrm{~L}$ & 1.4 & 40 & 2.45 & 45.67 \\
\hline & & $\mathrm{Ck}$ & $75-100$ & 553.6 & 176.7 & 269.7 & SCL & 1.4 & 37 & 2.34 & 41.34 \\
\hline & \multirow{2}{*}{$\mathrm{P}_{3}$} & Ap & $0-25$ & 282 & 148 & 534 & $\mathrm{C}$ & 1.26 & 52 & 2.63 & 18.7 \\
\hline & & $\mathrm{Bk}$ & $25-80$ & 171 & 135 & 377 & $\mathrm{SC}$ & 1.31 & 49 & 1.6 & 33 \\
\hline & \multirow{2}{*}{$\mathrm{P}_{4}$} & Ap & $0-25$ & 289 & 437 & 274 & $\mathrm{CL}$ & 1.19 & 55 & 2.92 & 9.89 \\
\hline & & $\mathrm{Bk}$ & $25-80$ & 226 & 490 & 284 & $\mathrm{CL}$ & 1.26 & 51 & 2.05 & 1.27 \\
\hline
\end{tabular}

Table 4: Calcium carbonate (CaCO3), cation exchange capacity (CEC), Organic matter (OM), EC and pH of studied pedon.

\begin{tabular}{|c|c|c|c|c|c|c|c|c|}
\hline \multirow{2}{*}{ governorate } & \multirow{2}{*}{ Pedon } & \multirow{2}{*}{ Horizon } & Depth & $\mathrm{CaCO}_{3}$ & CEC & O.M & \multirow{2}{*}{$\frac{\text { EC }}{\mathrm{dS} . \mathrm{m}^{-1}}$} & \multirow[t]{2}{*}{$\overline{\mathrm{pH}}$} \\
\hline & & & $\mathrm{cm}$ & \multicolumn{3}{|c|}{ g. $\mathrm{kg}^{-1}$} & & \\
\hline \multirow{11}{*}{ 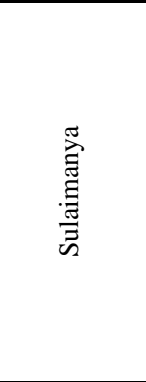 } & \multirow{4}{*}{$\mathrm{P} 1$} & Ap & $0-25$ & 175 & 20.7 & 27.7 & 0.16 & 7.9 \\
\hline & & $\mathrm{Bt}_{1}$ & $25-35$ & 180 & 23.9 & 37.3 & 0.12 & 7.7 \\
\hline & & $\mathrm{Bt}_{2}$ & $35-70$ & 175 & 25.8 & 17.5 & 0.10 & 7.8 \\
\hline & & $\mathrm{Bt}_{3}$ & $70-150$ & 178 & 30.9 & 17.5 & 0.17 & 7.1 \\
\hline & \multirow{4}{*}{$\mathrm{P} 2$} & Ap & $0-25$ & 268 & 19.2 & 23.6 & 0.24 & 7.9 \\
\hline & & $\mathrm{AB}$ & $25-80$ & 242 & 17.7 & 18.5 & 0.12 & 7.8 \\
\hline & & $\mathrm{Bt}$ & $80-120$ & 222 & 21.6 & 37.2 & 0.14 & 7.8 \\
\hline & & Btk & $120-180$ & 340 & 19.2 & 12.4 & 0.16 & 7.1 \\
\hline & \multirow{2}{*}{ P3 } & Ap & $0-20$ & 56 & 11.5 & 9.1 & 0.55 & 8.4 \\
\hline & & $\mathrm{AB}$ & $20-70$ & 103 & 10.7 & 7.6 & 0.60 & 8.3 \\
\hline & $\mathrm{P} 4$ & Ap & $0-25$ & 163 & 20.1 & 20 & 0.44 & 7.8 \\
\hline
\end{tabular}




\begin{tabular}{|c|c|c|c|c|c|c|c|c|}
\hline & & $\mathrm{Bt}$ & $25-80$ & 216 & 10.1 & 6.2 & 0.36 & 7.6 \\
\hline & \multirow{2}{*}{ P5 } & Ap & $0-20$ & 163 & 9.5 & 4.2 & 0.25 & 8.3 \\
\hline & & $\mathrm{Bt}$ & $20-75$ & 192 & 9.1 & 3.4 & 0.57 & 8.1 \\
\hline & \multirow{2}{*}{ P6 } & Ap & $0-25$ & 64 & 21.8 & 28.9 & 0.31 & 8.2 \\
\hline & & $\mathrm{Bt}$ & $25-75$ & 162 & 12.1 & 9.1 & 0.84 & 8.0 \\
\hline \multirow{10}{*}{$\begin{array}{l}\overline{\overline{0}} \\
\overline{\dot{1}}\end{array}$} & \multirow{3}{*}{ P1 } & Ap & $0-25$ & 293 & 26.5 & 30.7 & 0.18 & 8.2 \\
\hline & & Bt1 & $25-75$ & 285 & 27.8 & 23.4 & 0.28 & 8.2 \\
\hline & & Bt2 & $75-100$ & 343 & 24.7 & 19.7 & 0.56 & 8.2 \\
\hline & \multirow{3}{*}{$\mathrm{P} 2$} & Ap & $0-25$ & 267 & 29.3 & 51.1 & 0.36 & 8.3 \\
\hline & & $\mathrm{Bk}$ & $25-75$ & 298 & 23.3 & 22.6 & 0.14 & 7.9 \\
\hline & & $\mathrm{Ck}$ & $75-100$ & 320 & 22.5 & 20.4 & 0.16 & 7.9 \\
\hline & \multirow{2}{*}{ P3 } & Ap & $0-25$ & 193 & 12.1 & 17.3 & 0.44 & 8.0 \\
\hline & & $\mathrm{Bk}$ & $25-80$ & 394 & 10.2 & 7.6 & 0.31 & 8.4 \\
\hline & \multirow{2}{*}{$\mathrm{P} 4$} & Ap & $0-25$ & 185 & 20.2 & 11.5 & 0.90 & 8.4 \\
\hline & & $\mathrm{Bk}$ & $25-80$ & 202 & 10.2 & 7.9 & 0.52 & 8.3 \\
\hline
\end{tabular}

It well knows that hydraulic conductivity depends strongly on texture and porosity, however in some sites had similar texture but differed in Kast. This may be attributed to other factors such as cementing agents and their interaction. The highest values of Kast in studied sites were $60.89,60.34,77.73,55.12$ and $88.67 \mathrm{~cm} . \mathrm{hr}^{-1}$ recorded in surface horizons of P1, P2, P6 (Sulaimanya sites) and P1, P2 (Erbil sites) respectively. The reason of upturn value in hydraulic conductivity was the effect of organic matter content (Tables 4) which led to decrease the bulk density and higher porosity, MWD (Table 3).

These sites have been placed within the classification very dense vegetation, as reflected the improvement in the physical and chemical characteristics of soil to the presence of good vegetation cover.

Pedon 3 in Erbil site situated within the classification dense vegetation, due the good of physical and chemical properties led to the formation of good structure $(\mathrm{MWD}=2.63 \mathrm{~mm}$ ) and hydraulic conductivity (Kast= $\left.18.7 \mathrm{~cm} . \mathrm{h}^{-1}\right)$ correlation with higher content of organic matter $\left(\mathrm{OM}=17.3 \mathrm{~g} . \mathrm{kg}^{-1}\right)$. While the pedon 3 Sulaimanya site and pedon 4 Erbil site situated within the classification moderate vegetation. The reason, to have these sites chemical and physical quality properties (Table 3 and 4) less than limits required to field an integrated soil quality, so these soils cover a moderate density line with properties quality. Pedon 4 Sulaimanya site has good physical and chemical characteristics (Table 3 and 4) for plant growth, but the time sampling of this site was where no agricultural exploitation in that area, so is placed within a classification no vegetation. Pedon 5 Sulaimanya site placed within classification poor vegetation, was due to high free iron oxides content in this sites $\left(\mathrm{Fe}_{2} \mathrm{O}_{3}=14 \mathrm{~g}\right.$. kg $\left.{ }^{-1}\right)$ with decreased in organic content $\left(\mathrm{OM}=4.2 \mathrm{~g}^{-\mathrm{kg}^{-1}}\right)$, casing to developed soil structure, and increasing of MWD and GMD, at the meantime bulk density was increased with decreasing in porosity of the surface horizon.

\section{Conclusion}

Distribution of vegetation cover were affected by some of the physical and chemical characteristics, Areas of very dense and dense vegetation indicate that the physical characteristics of the soil good, It is found that the type of soil texture C-CL, high porosity, high hydraulic conductivity (Ksat) which is influenced by the content of organic matter helped in obtaining high density of vegetation. The no vegetation area increased because some barren soil and water bodies increased in Sulaimanya. The dense vegetation area increased too in Sulaimanya and poor vegetation decreased because the agriculture exploitation of the land but the other vegetation classes such as moderate, very dense vegetation decrease.

\section{References}

[1]. Allen, E. 1991 Temporal and spatial organization of desert plant communities. In: Skujins J (ed.) Semiarid lands and deserts. New York. 193-208.

[2]. Black, C. A. 1965a. Methods of Soil Analysis. Physical \& mineralogical properties. Madison. Wisc., USA.

[3]. Black, C. A. 1965b. Methods of Soil Analysis. Chemical \& Biological properties. Madison. Wisc. USA.

[4]. Dabrowska-Zielinska, K., A. Kogan, F. Ciolkosz, M.Gruszczynska and W.Kowalik. 2002. Modelling of crop growth conditions and crop yield in Poland using AVHRR-based indices. International Journal of Remote Sensing, 23, 1109-1123.

[5]. Fadhil, A. M. 2011. Drought mapping using Geoinformation technology for some sites in the Iraqi Kurdistan region. International Journal of Digital Earth, 4, 3, 239 - 257.

[6]. Jain, S. K., R. Keshri, A.Goswami, A.Sarkar and A. Chaudhry. 2009. Identification of drought-vulnerable areas using NOAAAVHRR data. International Journal of Remote Sensing, 30, No.10, 2653-2668.

[7]. Jensen, J.R. (2000). Remote Sensing of the Environment: An Earth Resource Perspective. New Jersey, USA: Prentice Hall.

[8]. Kunkel ML, Flores AN, Smith TJ, McNamara JP, Benner SG (2011) A simplified approach for estimating soil carbon and nitrogen stocks in semi-arid complex terrain. Geoderma 165: 1-11

[9]. Li, J., J. Lewis. 2004. Evaluation of land performance in Senegal using multi-temporal NDVI and rainfall series. Journal of Arid Environment, Vol. 59, pp. 463-480.

[10]. Prince, S. D. 2002. Spatial and temporal scales of measurement of desertification[D]// Stafford-Smith M, Reynolds J F. Global Desertification: Do Humans Create Deserts? [M]. Berlin: Dahlem University. 
[11]. Rasheed, A. M. M. 2010. Analysis of rainfall drought periods in north of Iraq using standard precipitation index SPI. Al-Rafidain Engineering, 18 (2), pp. 60-72.

[12]. Scanlon TM, J. Albertson, K. Caylor and C. Williams .2002. Determining land surface fractional cover from NDVI and rainfall time series for a savanna ecosystem. Remote Sens Environ 82: 376-388.

[13]. Singh, R. P., S. Roy and F. Kogan. 2003. Vegetation and temperature condition indices from NOAA-AVHRR data for drought monitoring over India. International Journal of Remote Sensing, 24, No. 22, 4393-4402.

[14]. United States Department of Agriculture, Agricultural Research Service, Natural Resources Conservation Service, Soil Quality Institute. 2001. Soil Quality Test Kit Guide.http://www.usgs.gov.2012.

[15]. Vicente-Serrano, S., J. M. Cuadrat-Prats and A. Romo. 2006. Early prediction of crop productivity using drought indices at different time scales and remote sensing data: application in the Ebro valley (north east Spain). International Journal of Remote Sensing, 27, pp. 511-518.

[16]. Wessels, K. J., S. D Prince, P. E. Frost, and Z. y. Van. 2004. Assessing the effects of human-induced land degradation in the former homelands of northern South Africa with a $1 \mathrm{~km}$ AVHRR NDVI time-series [J]. Remote Sensing of Environment, 5(9), 47-67.

[17]. Yousef Y. Aldakheel, Adel M. Elprince, Masoud Abdel Aatti. 2006. MAPPING VEGETATION AND SALINE SOIL USING NDVI IN ARID IRRIGATED LANDS, Water Studies Center, King Faisal University, POBox 420, Hofuf, Saudi Arabia ASPRS 2006 Annual Conference Reno, Nevada / May 1-5. 